$\mathrm{Nr} 7$

WARSZAWA-KRAKÓW 2004

KRZYSZTOF WIEDERMANN

Uniwersytet Jagielloński, Kraków

\title{
Wybrane problemy ksztaltowania się nowej struktury przemysłowej na obszarze GOP
}

Od ponad dwustu lat na obszarze dzisiejszego Górnośląskiego Okręgu Przemysłowego dominował model gospodarki opartej na węglu. Tworzone na tym terenie przedsiębiorstwa wykształciły strukturę przemysłową zdominowaną przez „,przemysł ciężki”, w którym najważniejszą rolę, mierzoną zarówno liczbą pracujących, majątkiem trwałym, jak i wartością sprzedaną produkcji, odgrywało górnictwo węgla kamiennego, hutnictwo żelaza, koksownictwo i energetyka (ryc. 1).

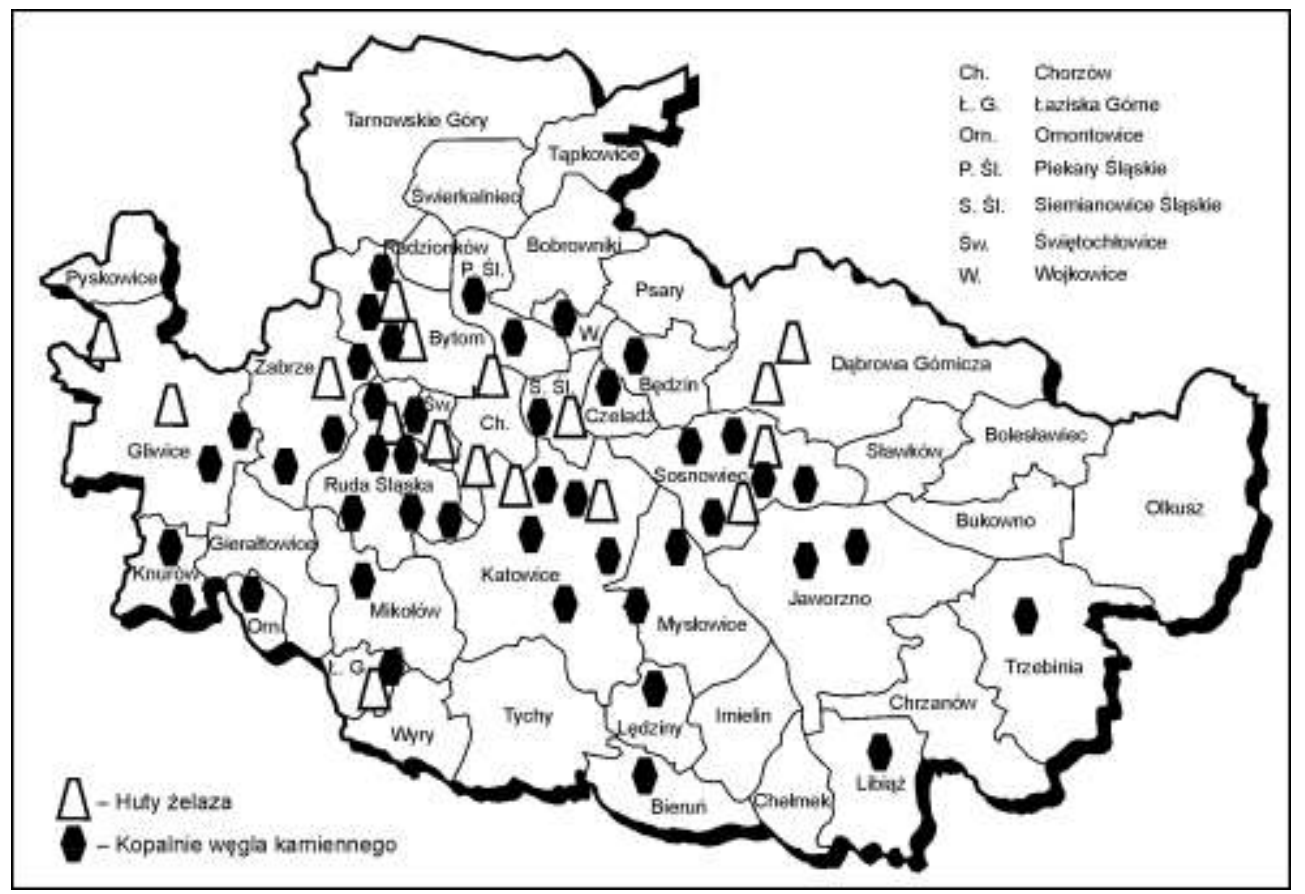

Ryc. 1. Rozmieszczenie kopalń węgla kamiennego i hut żelaza na obszarze GOP-u przed 1990 rokiem

Źródło: opracowanie własne 
Na obszarze Górnośląskiego Okręgu Przemysłowego problemy ekonomiczne przedsiębiorstw wynikające $\mathrm{z}$ niedostosowania do warunków rynkowych po transformacji gospodarczej lat dziewięćdziesiątych XX wieku były szczególnie nasilone, ze względu na dużą liczbę zakładów oraz strukturę gospodarczą regionu.

\section{PRZEKSZTAŁCENIA STRUKTURALNE PRZEDSIĘBIORSTW}

Zmiana warunków gospodarczych po 1989 roku spowodowała reorganizację przedsiębiorstw (Tkocz 2001, Wiedermann 2002). Dotyczyło to zarówno przekształceń wewnętrznych firm, jak i zmian w powiązaniach z podmiotami zewnętrznymi. Jednym z elementów przemian organizacyjnych był proces outsourcingu, tzn. podzlecania cześci produkcji i usług firmom zewnętrznym. Najczęściej były to przedsiębiorstwa, które wcześniej funkcjonowały jako zakłady firmy macierzystej, a w wyniku restrukturyzacji organizacyjnej uzyskiwały własną osobowość prawną. Najczęściej wyodrębniano zakłady usługowe, takie jak: transport wewnętrzny i zewnętrzny, jednostki remontowe, porządkowe i świadczące usługi socjalne. Ich dotychczasowa działalność rozszerzała się na inne przedsiębiorstwa, co zapewniało większe możliwości rozwoju. Proces usamodzielniania poprzez tworzenie nowych przedsiębiorstw z czasem objął również wydziały produkcyjne.

Restrukturyzacja organizacyjna przedsiębiorstw sprzyjała też możliwości pozyskania kapitału zewnętrznego. Dla wyodrębnionych zakładów łatwiej było znaleźć inwestora. Najczęściej przedsiębiorstwa posiadały w tych jednostkach część udziałów bądź akcji, przez co zyski tam generowane mogły być do nich odprowadzane.

Ogrom wydatków związanych z modernizacją technologiczną i dostosowaniem asortymentu produkcji do wymogów rynku wymagał poniesienia znacznych nakładów kapitałowych. Przedsiębiorstwa będące wcześniej własnością państwa nie mogły liczyć na wystarczające dotacje ze względu na ograniczony budżet. $Z$ wypracowanych przez siebie środków oraz z zaciągniętych kredytów rozpoczęły przekształcenia. Po pewnym czasie okazało się, że część z przedsiębiorstw nie jest w stanie samodzielnie ukończyć procesu modernizacji i konieczne jest wniesienie kapitału zewnętrznego. Zaistniała potrzeba przynajmniej częściowej prywatyzacji tych przedsiębiorstw.

Do zmian organizacyjnych należą także zmiany w sposobie sprzedaży. Gospodarka wolnorynkowa wymusiła rozbudowę komórek zajmujących się zbytem towarów i powstanie działów marketingu, badających zapotrzebowanie rynku oraz wynajdujących nisze popytowe w zakresie sprzedawanych wyrobów. Część firm utworzyła własne sieci dealerów zajmujących się sprzedażą.

Trochę odmienny problem stanął przed miejscowym przemysłem wydobywczym. O ile bardzo kosztowne przemiany modernizacyjne oraz nowe inwestycje stanowią do dzisiaj kluczowy problem dla dalszego rozwoju hutnictwa, energetyki, przedsiębiorstw przemysłu metalowego itd., o tyle dla górnictwa największym problemem jest duża nadprodukcja węgla. Przekształcenia w tym dziale wiążą się z dużymi kosztami społecznym w związku z konieczną redukcją zatrudnienia. Stąd w programach przemian dla górnictwa największy nacisk kładzie się na łagodzenie sytuacji społecznej, co sprowadza się do propozycji 
odpraw górniczych, przejść na wcześniejsze emerytury, aktywizacji zawodowej, szkoleń i przekwalifikowania dotychczasowych pracowników kopalń.

\section{NAPŁYW NOWYCH INWESTYCJI PRZEMYSŁOWYCH}

Procesy transformacji gospodarczej regionu śląskiego pociąnnęły za sobą duże bezrobocie strukturalne. Rozwiązanie tego problemu wymaga podjęcia działań administracyjnych na różnych szczeblach, wspomagających napływ nowych inwestycji. Korzyści z tych inwestycji to głównie stworzenie nowych miejsc pracy oraz zmiana struktury przemysłu poprzez transfer wiedzy i nowoczesnych technologii. W działania zarówno promocyjne, jak i oferowanie konkretnej pomocy dla inwestorów zaangażowali się decydenci miast, lokalni liderzy, istniejące tu instytucje i ośrodki badawczo-rozwojowe oraz administracja państwowa. Efektem tych działań było utworzenie szeregu instytucji wspierających napływ do tego obszaru nowych inwestycji. Wśród nich najważniejsze to:

- Katowicka Specjalna Strefa Ekonomiczna,

- regionalne i lokalne agencje rozwoju regionalnego,

- parki technologiczne,

- inkubatory przedsiębiorczości.

Katowicka Specjalna Strefa Ekonomiczna została utworzona 18 czerwca 1996 roku na powierzchni 827,6 ha. Na obszarze Górnośląskiego Okręgu Przemysłowego obejmuje trzy podstrefy: gliwicką, sosnowiecko-dąbrowską i tyską. Poza tym obszarem istnieje jeszcze jastrzębsko-żorska podstrefa KSSE. Celem jej funkcjonowania jest promocja gospodarcza regionu, stworzenie zachęt ekonomicznych dla dużych, strategicznych inwestorów, stworzenie nowych miejsc pracy oraz restrukturyzacja istniejącego przemysłu. W ramach ulg dla inwestorów wprowadzono zwolnienie całości dochodu $\mathrm{z}$ opodatkowania podatkiem dochodowym przez 10 lat i 50\% dochodu przez kolejne 5 lat, jeżeli wydatki inwestycyjne na terenie strefy przekroczą $2 \mathrm{mln}$ ECU.

Od 1 stycznia 2001 roku przepisy dotyczące korzystania z ulg podatkowych zostały dostosowane do uregulowań przyjętych w krajach członkowskich Unii Europejskiej. W tym celu została uchwalona ustawa o warunkach udzielania i nadzorowania pomocy publicznej dla przedsiębiorców oraz znowelizowana ustawa o specjalnych strefach ekonomicznych. Inwestor ma obecnie możliwość skorzystania z regionalnej pomocy inwestycyjnej, co oznacza zwolnienie $\mathrm{z}$ podatku dochodowego $\mathrm{w}$ wysokości do $50 \%$ wartości początkowych nakładów inwestycyjnych lub z regionalnej pomocy na zatrudnienie związanej z nowymi inwestycjami, gdzie zwolnienie z podatku wynosi do 50\% kosztów pracy poniesionych przez inwestora w ciagu 2 lat.

Struktura nowych inwestycji przemysłowych (ryc. 2, 3) cechuje się pewną dynamiką czasową, jak i zróżnicowaniem przestrzennym w zależności od lokalizacji danej podstrefy. W pierwszym okresie funkcjonowania do strefy zaczęły napływać inwestycje głównie z branży motoryzacyjnej. Miało to szczególnie duże nasilenie na obszarach podstrefy gliwickiej i tyskiej (tab. 1). 
Tabela 1. Rozmieszczenie nowych inwestycji przemysłu motoryzacyjnego w KSSE

\begin{tabular}{|c|c|c|c|}
\hline Lp. & Przedsiębiorstwo & Rodzaj działalności & $\begin{array}{c}\text { Po- } \\
\text { wierzchnia } \\
\text { (ha) }\end{array}$ \\
\hline \multicolumn{4}{|c|}{ podstrefa gliwicka } \\
\hline 1 & Opel Polska GM & produkcja samochodów & 73,10 \\
\hline 2 & SILS Centre Gliwice* & branża motoryzacyjna & \\
\hline 3 & Sapa Autoplastics & $\begin{array}{l}\text { produkcja elementów plastikowych do sa- } \\
\text { mochodów }\end{array}$ & 4,30 \\
\hline 4 & HP Polska & $\begin{array}{l}\text { produkcja elementów wygłuszających do } \\
\text { samochodów }\end{array}$ & 2,50 \\
\hline 5 & Autorobot Strefa & produkcja linii do zgrzewania & 2,50 \\
\hline 6 & Fabryka Plastików Gliwice & $\begin{array}{l}\text { produkcja elementów plastikowych do sa- } \\
\text { mochodów }\end{array}$ & 3,00 \\
\hline 7 & $\begin{array}{l}\text { Lucas Varity Braking Systems } \\
\text { Polska TRW }\end{array}$ & produkcja zespołów pomp hamulcowych & 6,50 \\
\hline 8 & COMBI & galanteria samochodowa & 0,47 \\
\hline 9 & JMS & branża motoryzacyjna & 2,44 \\
\hline 10 & $\begin{array}{l}\text { Teneco Automotive Eastern } \\
\text { Europe }\end{array}$ & produkcja amortyzatorów i tłumików & 10,52 \\
\hline 11 & Automotosystems & branża motoryzacyjna & 0,99 \\
\hline \multicolumn{4}{|c|}{ podstrefa tyska } \\
\hline 1 & $\begin{array}{l}\text { Delphi Polska Automotive } \\
\text { Systems }\end{array}$ & produkcja elektroniki samochodowej & 11,21 \\
\hline 2 & $\mathrm{VAB}$ & produkcja wytłoczek karoseryjnych & 5,04 \\
\hline 3 & Isuzu Motors Polska & produkcja silników samochodowych & 34,53 \\
\hline 4 & Lear Corporation Poland II & branża motoryzacyjna & 11,76 \\
\hline 5 & Butz-Ieper Polska & branża motoryzacyjna & 1,98 \\
\hline 6 & Manuli & branża motoryzacyjna & 4,00 \\
\hline 7 & Toyo & branża motoryzacyjna & 3,45 \\
\hline 8 & Huf Polska & branża motoryzacyjna & 3,37 \\
\hline \multicolumn{4}{|c|}{ podstrefa sosnowiecko-dąbrowska } \\
\hline 1 & Pol-Disc Strefa & produkcja układów hamulcowych & 17,98 \\
\hline 2 & Ergom Poland & $\begin{array}{l}\text { produkcja elementów plastikowych do sa- } \\
\text { mochodów }\end{array}$ & 4,34 \\
\hline 3 & AV-EL & $\begin{array}{l}\text { produkcja elementów plastikowych do sa- } \\
\text { mochodów }\end{array}$ & 1,44 \\
\hline 4 & Berger & tkaniny i akcesoria do samochodów & 5,93 \\
\hline
\end{tabular}

* - kooperant Opla

Źródło: Opracowanie własne na podstawie danych Katowickiej Specjalnej Strefy Ekonomicznej 


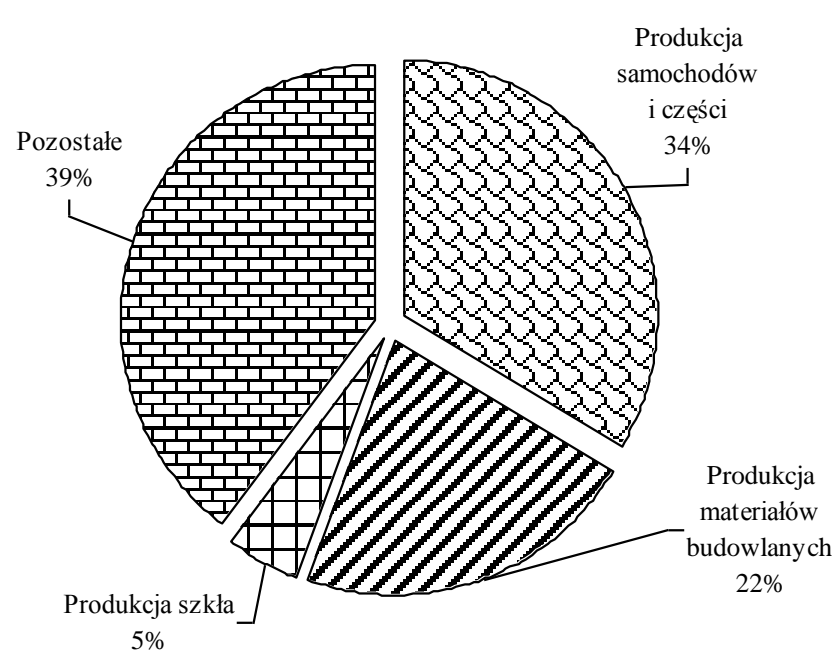

Ryc. 2. Struktura inwestycji w KSSE pod względem liczby podmiotów

Źródło: opracowanie własne na podstawie danych KSSE

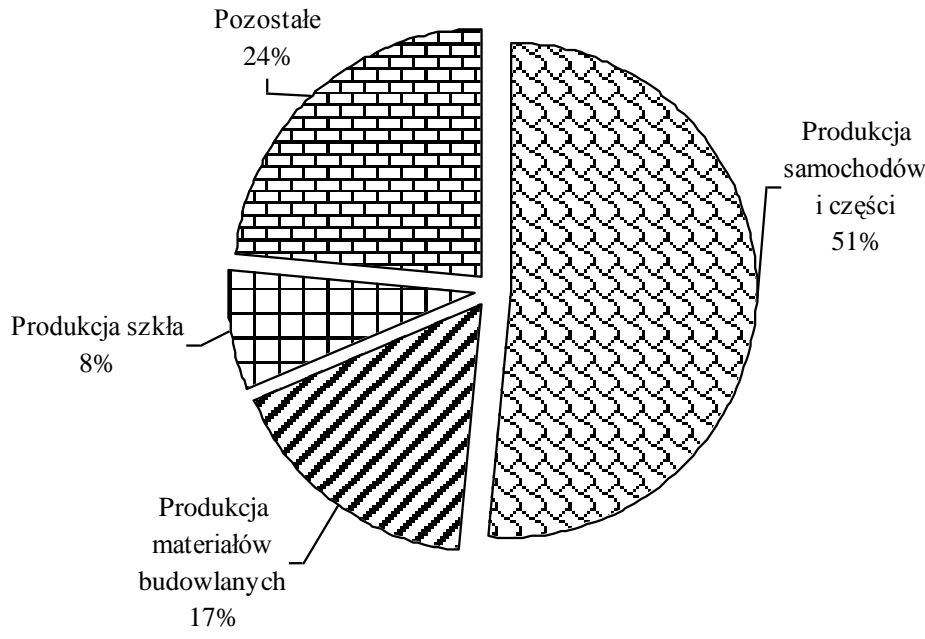

Ryc. 3. Struktura inwestycji w KSSE pod względem zajmowanej powierzchni gruntów

Źródło: opracowanie własne na podstawie danych KSSE

Największym nowym inwestorem w branży motoryzacyjnej w Górnośląskim Okręgu Przemysłowym jest fabryka Opel Polska w Gliwicach. Zakład rozpoczął produkcję w kwietniu 1998 roku. Cztery miesiące później pierwsza Astra Classic opuściła linię montażowa. W roku 2000 Opel Polska, jako jedyny na świecie zakład koncernu GM, rozpoczął produkcję nowego mikrowana Opla - Agili. Obecnie ponad 95\% produkcji tego modelu 
jest eksportowane do większości krajów europejskich. Opel zainwestował w Gliwicach $550 \mathrm{mln}$ USD, a na terenie zakładu zatrudnionych jest ponad 2000 pracowników. Jest on jednym z największych inwestorów zagranicznych na Śląsku, a jego obecność przyczyniła się do pobudzenia gospodarczego tego regionu oraz pozytywnych zmian w strukturze przemysłu. Zakład składa się z tłoczni, wydziału karoserii, lakierni, wydziału montażu głównego oraz dwóch głównych działów nie zajmujących się bezpośrednio produkcją: wydziału jakości i wydziału gospodarki materiałowej.

W ostatnich latach do KSSE zaczynają napływać nowe inwestycje z zakresu produkcji oprogramowania i usług informatycznych. Jednym z obszarów, na których rozwijana jest ta działalność to „Technopark Tychy” istniejący w ramach tyskiej podstrefy KSSE. Na terenie Technoparku preferowanych jest kilka rodzajów działalności - prowadzenie prac badawczo-rozwojowych w dziedzinie nauk przyrodniczych i technicznych, produkcja maszyn biurowych i komputerów, sprzętu i aparatury radiowej, telewizyjnej i komunikacyjnej, instrumentów medycznych, precyzyjnych i optycznych. Dotychczas na jego obszarze swoją działalność w branży IT uruchomiły firmy: 2Si Software\&Serwis, Micomp Systemy Komputerowe i Dot. Serwis.

Z ważnych inwestycji należących do sektora IT należy wymienić działające w Gliwicach Przedsiębiorstwo Wdrażania Postępu Technicznego WASKO założone przez specjalistów z dziedziny fizyki, elektroniki, informatyki, metrologii i mechaniki, byłych pracowników Politechniki Śląskiej w Gliwicach. Obecnie firma ta ma cztery oddziały w Gliwicach, jeden Warszawie i zatrudnia 220 pracowników. W strukturach organizacyjnych przedsiębiorstwa działają zakłady: Ekspertyz i Realizacji Projektów, Informatyki, Realizacji Systemów Teleinformatycznych, Aparatury Kontrolno-Pomiarowej i Teletransmisji, Autoryzowany Serwis HP oraz Ośrodek Szkoleniowy. W 2000 roku powstał podmiot zależny WASKOm, którego docelowa siedziba będzie wybudowana na zakupionych terenach (1,6 ha) w gliwickiej podstrefie KSSE. Obecnie firma prowadzi prace dla sektora energetycznego oraz automatyki oferując kompleksowe systemy informatyczne. Przedsiębiorstwo zatrudnia 20 osób. Przedmiotem działalności WASKOm jest świadczenie kompleksowych usług teleinformatycznych dla sektora energetycznego. Drugim podmiotem wchodzącym w skład grupy kapitałowej PWPT WASKO jest portal internetowy hoga.pl.

Sosnowiecko-dąbrowska podstrefa KSSE cechuje się nieco odmienną od gliwickiej i tyskiej strukturą przemysłu wśród dotychczasowych inwestycji. Poza przedstawionymi w tabeli 1 inwestycjami motoryzacyjnymi dominującą rolę odgrywa w tej podstrefie produkcja materiałów budowlanych i elementów wykończenia wnętrz, stolarki okiennej oraz wytwarzanie szkła. W zakresie skupienia inwestycji produkcji materiałów budowlanych największą rolę odgrywa podstrefa ustanowiona na zapleczu Huty „Katowice”, obejmująca obszar 77,49 ha. Jedna z ważniejszych istniejących tam inwestycji to EkoCem o wartości 172 mln PLN - wspólne przedsięwzięcie Huty Katowice i inwestora zewnętrznego w zakresie produkcji cementu, betonu i półfabrykatów betonowych z przeróbki materiałów odpadowych pochodzących z cyklu produkcyjnego huty. Największą inwestycję w tej podstrefie, szacowaną na około $400 \mathrm{mln}$ PLN, rozpoczął amerykański koncern Guardian w zakresie produkcji szkła typu ,float”.

Wśród regionalnych agencji działających na rzecz rozwoju województwa należy wymienić Górnośląską Agencję Rozwoju Regionalnego (GARR) oraz Górnośląską Agencję Przekształceń Przedsiębiorstw (GAPP). Obie instytucje powstały w pierwszej połowie lat dziewięćdziesiątych. Jednym z głównych działań prowadzonych przez nie jest promocja gospodarcza regionu w kraju i za granica, mającą na celu zachęcenie przedsiębiorców kra- 
jowych i zagranicznych do inwestowania w województwie śląskim, jako jeden z elementów restrukturyzacji gospodarki regionu.

Bardziej lokalny charakter ma tworzenie inkubatorów przedsiębiorczości. Zazwyczaj powstają one w wyniku działań lokalnych agencji rozwoju finansowanych ze środków gmin. Przykładem takiej inicjatywy jest Gliwicki Inkubator Przedsiębiorczości, który powstał w celu wspierania działalności nowo tworzonych małych i średnich firm. Cel ten realizowany jest poprzez:

- zapewnienie podmiotom miejsca, w którym mogą rozpocząć działalność;

- oferowanie niższych od rynkowych opłat za czynsz;

- świadczenie usług w zakresie rachunkowości, konsultacji prawnych, informacji gospodarczej, reklamy, promocji i marketingu;

- świadczenie usług doradczych;

- świadczenie usług administracyjno-biurowych;

- organizowanie szkoleń z zakresu organizacji i zarządzania firmą, marketingu i finansów firmy, ubezpieczeń obowiązkowych, podstaw prawnych;

- udostępnianie sal konferencyjno-wykładowych.

W Gliwickim Inkubatorze działalność gospodarczą prowadzą podmioty skierowane na innowacyjność i wysokie technologie, stwarzające nowe miejsca pracy dla absolwentów wyższych uczelni. Wiąże się to z bezpośrednim sąsiedztwem Politechniki Śląskiej oraz dużym potencjałem naukowym w Gliwicach. Z oferty Inkubatora korzysta dzisiaj 25 podmiotów gospodarczych, z czego aż 12 w branży IT (tab. 2).

Tabela 2. Przedsiębiorstwa branży IT działające w Gliwickim Inkubatorze Przedsiębiorczości

\begin{tabular}{|l|l|l|}
\hline Lp. & \multicolumn{1}{|c|}{ Przedsiębiorstwo } & \multicolumn{1}{c|}{ Rodzaj dzialalności } \\
\hline 1 & ANT & $\begin{array}{l}\text { Tworzenie, serwis i sprzedaż oprogramowania kompute- } \\
\text { rowego, prowadzenie serwisów i baz danych w Interne- } \\
\text { cie, wyszukiwanie i gromadzenie informacji, działalność } \\
\text { doradcza i szkoleniowa; handel i serwis sprzętu elektro- } \\
\text { nicznego }\end{array}$ \\
\hline 2 & Click 5 & $\begin{array}{l}\text { Projektowanie serwisów internetowych, prowadzenie } \\
\text { internetowych kampanii reklamowych, tworzenie interne- } \\
\text { towych serwisów tematycznych }\end{array}$ \\
\hline 3 & elCOM INTERNET & $\begin{array}{l}\text { Usługi komputerowe w zakresie projektowania, progra- } \\
\text { mowania, konfiguracji, montażu i rozruchu systemów } \\
\text { komputerowych, systemów elektroniki przemysłowej }\end{array}$ \\
\hline 4 & ES-System & Produkcja i projektowanie systemów oświetleniowych \\
\hline 5 & Fargo & $\begin{array}{l}\text { Tworzenie serwisów WwW, prezentacji multimedial- } \\
\text { nych; usługi poligraficzne i reklamowe, prowadzenie } \\
\text { kursów i konsultingu, dostarczanie usług internetowych, } \\
\text { wykonywanie oprogramowania }\end{array}$ \\
\hline 6 & $\begin{array}{l}\text { Formida - Laboratorium } \\
\text { informatyki }\end{array}$ & Usługi informatyczne - produkcja oprogramowania \\
\hline 7 & Intex & $\begin{array}{l}\text { Dostawa urządzeń sterujących i automatyki, szkolenia, } \\
\text { konsultacje wdrażania systemów }\end{array}$ \\
\hline
\end{tabular}




\begin{tabular}{|l|l|l|}
\hline 8 & $\begin{array}{l}\text { Instytut Systemów } \\
\text { Przestrzennych i Katastralnych }\end{array}$ & $\begin{array}{l}\text { Tworzenie systemów informacji przestrzennej (sip) i sys- } \\
\text { temów katastralnych, doradztwo, kształcenie specjalistów }\end{array}$ \\
\hline 9 & $\begin{array}{l}\text { KRUPA - Systemy } \\
\text { Informatyczne }\end{array}$ & $\begin{array}{l}\text { Produkcja i sprzedaż oprogramowania komputerowego } \\
\text { (systemów informatycznych) oraz licencji użytkowych; } \\
\text { pełny zakres usług informatycznych }\end{array}$ \\
\hline 10 & $\begin{array}{l}\text { Ośrodek Badań, Atestacji } \\
\text { i Certyfikacji 'OBAC' }\end{array}$ & $\begin{array}{l}\text { Prowadzenie badań atestacyjnych i certyfikacyjnych, } \\
\text { opracowywanie ekspertyz technicznych i ekonomicznych } \\
\text { oraz wdrażanie systemów jakości; opracowywanie do- } \\
\text { kumentacji projektowych, konstrukcyjnych i technolo- } \\
\text { gicznych }\end{array}$ \\
\hline 11 & Polgat & $\begin{array}{l}\text { Tworzenie i doskonalenie systemów zapewniania jakości, } \\
\text { seminaria, szkolenia, produkty programowe, doradztwo; } \\
\text { usługi w zakresie konsultacji, projektowania, programo- } \\
\text { wania, produkcji, instalacji, rozruchu i serwisu systemów } \\
\text { sterowania, automatyki i nadzoru technologicznego pro- } \\
\text { cesów przemysłowych i laboratoryjnych; usługi informa- } \\
\text { tyczne }\end{array}$ \\
\hline 12 & $\begin{array}{l}\text { Firma Handlowa } \\
\text { „PROSPECTA" }\end{array}$ & $\begin{array}{l}\text { Kompleksowa realizacja systemów audiowizualnych } \\
\text { (wyposażenie sal konferencyjnych i szkoleniowych) dla } \\
\text { odbiorców instytucjonalnych }\end{array}$ \\
\hline
\end{tabular}

Źródło: Opracowanie własne na podst. danych Agencji Rozwoju Lokalnego, Gliwice

\section{PERSPEKTYWY DALSZEGO ROZWOJU PRZEMYSŁU}

Zachowanie konkurencyjności gospodarczej regionu powoduje konieczność dalszych zmian w strukturze przemysłowej obszaru Górnośląskiego Okręgu Przemysłowego. Wciąż zmniejszający się popyt na wytwarzane tu dotychczas tradycyjne wyroby przemysłowe zmusza do poszukiwania nowej ścieżki rozwoju poprzez podejmowanie na tym obszarze działalności przemysłowych zaliczanych do przemysłu wysokiej techniki i szybkiego wzrostu. Wiąże się to nieodzownie z postulatem przejścia od gospodarki opartej na węglu do gospodarki opartej na wiedzy - GOW (Kukliński 2001). Z tego punktu widzenia konieczna staje się integracja świata biznesu, polityki i nauki w celu wypracowania nowych inicjatyw zmieniających strukturę gospodarki regionu. Dotychczasowe działania w tym zakresie powinny zostać zintensyfikowane. Zauważalna jest potrzeba rozbudowy parków przemysłowych i technologicznych oraz powstanie nowych inkubatorów przedsiębiorczości we współpracy z istniejącymi na tym obszarze jednostkami rozwojowo-badawczymi.

Dla zwiększenia atrakcyjności regionu dla inwestorów zewnętrznych konieczne jest kreowanie nowego wizerunku, rewitalizacja obszarów zdegradowanych - szczególnie w centralnej części okręgu oraz przeniesienie wielkopowierzchniowych zakładów przemysłowych z centrów miast do obszarów peryferyjnych. Wymogiem dalszego rozwoju jest także usprawnienie systemu komunikacyjnego szczególnie w zakresie połączeń transportu 
samochodowego i kolejowego. Dużą szansą dla regionu jest perspektywa budowy na tym obszarze autostrad A4 i A1, które to wraz z modernizacją LHS i drogi wodnej Odry umożliwią rozwój ponadregionalnych centrów logistyczno-spedycyjnych.

Dotychczasowe przemiany podążają w dobrym kierunku, jednak od tempa ich realizacji i czasu zakończenia będzie zależał sukces regionu. Trzeba mieć na względzie, że zachodzące przemiany są bardzo zróżnicowane w poszczególnych miastach regionu, co nie sprzyja harmonijnemu rozwojowi całego okręgu przemysłowego.

\section{Literatura}

Gospodarka oparta na wiedzy. Wyzwania dla Polski XXI wieku, 2001, red. A. Kukliński, Warszawa Materiaty Agencji Rozwoju Lokalnego (www.arl.pl/inkubator.html)

Materiały Katowickiej Specjalnej Strefy Ekonomicznej (www.ksse.com.pl)

Tkocz M., 2001, Restrukturyzacja przemystu regionu tradycyjnego, Katowice

Wiedermann K., 2002, Restrukturyzacja i modernizacja hutnictwa żelaza Górnoślaskiego Okręu Przemystowego (w druku) 